\title{
Evaluating the Efficiency of gamma Irradiated Frankincense against Isoprenaline Induced Myocardial Infarction in Rats
}

\author{
Ashraf M. Mounir, A.N. El shahat* and A.M. Abdul Azeem \\ Food Irradiation Research Department, National Centre for Radiation Research and \\ Technology, Atomic Energy Authority, Cairo, Egypt
}

\begin{abstract}
A B S T R A C T
Isoprenaline (ISO) is one of synthetic catecholamine that can be used as a model to produce myocardial infarction (MI). Frankincense is a gum resin that possesses anti-inflammatory and antioxidant activity. Gamma-irradiation is used for decontamination of Boswellia tears to achieve satisfactory microbiological quality and public health safety. Hence, examining the effect of gamma-irradiation on the contents of Boswellia oleo-gum resin and also investigating the role of gamma-irradiate frankincense aqueous extract (GFAE) against ISO-induced MI in rats were the two aims of this study. The total phenolic content and total flavonoids of frankincense has been significantly increased under the effect of gamma-rays in this work. Injection of isoprenaline hydrochloride $(100 \mathrm{mg} / \mathrm{kg} \mathrm{B}$.Wt./day) to rats resulted in cardiac oxidative stress, inflammation, hyper-lipidemia and increase cardiac marker enzymes. Treatment of rats with GFAE $(45 \mathrm{mg} / \mathrm{kg} /$ day) prior to injection of ISO provide significant cardio-protective effects evidenced by an obvious reduction in the level of cardiac marker enzymes, inflammatory factors and lipid contents with marked improvement in the cardiac antioxidant status and reduction of lipid peroxidation relative to untreated infarcted group. The study concluded gamma irradiation could be used as an efficient method for sterilization and increasing the active contents of frankincense. Also, gamma-irradiated frankincense can be used as an effective cardio protective natural agent in MI.
\end{abstract}
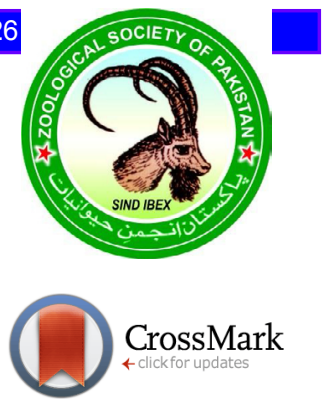

\section{INTRODUCTION}

$\mathrm{M}$ yocardial infarction (MI) is a major public health problem that occurs when the blood supply to a part of the heart is interrupted, causing death to the heart tissue. It is a cardiovascular disease that affecting the mechanical, electrical, structural, and biochemical properties of the heart (Upaganlawar et al. 2010). Catecholamines can lead to complex biochemical and structural changes that cause cellular damage and ultimately necrosis and can induce myocardial infarction (Zaki et al., 2014). Isoprenaline (ISO), a $\beta$-adrenoceptor agonist, is one of synthetic catecholamine and has been reported to causes severe oxidative stress in the myocardium, resulting in infarct-like necrosis of the heart muscle. Isoprenaline induces production of highly cytotoxic free radicals that stimulate lipid peroxidation which causes destruction and damage to the myocardial cell membrane (Zaafan et al., 2013). Therefore, isoprenaline is widely used as a model to produce MI in rats (Kannan and Quine, 2013). New therapies are needed to treat myocardial ischemia because current treatment has only a limited

\footnotetext{
Corresponding author: amrshahat22@yahoo.com 0030-9923/2019/0001-0219 \$ 9.00/0

Copyright 2019 Zoological Society of Pakistan
}

impact on survival and annual cost.

Frankincense (olibanum) is a gum resin that produced from Boswellia carteri tree. Boswellia carteri is a plant species of Burseraceae family which grows in different region of India. Frankincense oleogum resin is a complex mixture containing a series of mono-, sesqui-, di-, and triterpenoids and is used in traditional medicine in the treatment of inflammatory diseases, cough and asthma, as a diuretic, and as an emmenagogue. Also, the compounds extracted from olibanum resin, have shown various biological activities including anti-inflammatory activity, leukotriene biosynthesis-inhibitory activity, antitumor activity and immunomodulatory effects (Beheshti and Karimi, 2016; Zaki et al., 2014). In addition, boswellic acids are the major constituents of frankincense resin which are groups of pentacyclic terpenoids and have an antiproliferative effect on tumours (Al-Yasiry and Kiczorowska, 2016).

During air drying, collection, transportation, and storage; Frankincense oleogum resin is highly prone to get contaminated with microorganisms. Therefore, using of suitable method for sterilization and decontamination of Boswellia tears must be applied to achieve satisfactory microbiological quality and public health safety (Badr et al., 2016). Using of gamma sterilization is a feasible, less toxic more environmental-friendly way to remove 
microbial contamination and improving the nutritive quality of dry medicinal herbs than other decontamination methods (Hamza et al., 2012; Badr et al., 2016).

Thus, the aim of this work was to study the effect of gamma-radiation processing on the on the contents of total phenols and flavonoids of Boswellia oleo-gum resin. Also, this work aimed to study the effect of gamma-irradiated frankincense (olibanum) against Isoprenaline (ISO)induced myocardial infarction (MI) in rats.

\section{MATERIALS AND METHODS}

Frankincense (olibanum) oleogum resin of Boswellia carteri Birdw. (Burseraceae) was purchased from a local herbal store (Cairo, Egypt). Chemicals and reagents were purchased from Sigma Chemical Co. (St. Louis, MO, USA).

\section{Gamma irradiation treatment}

The frankincense oleogum resin was finely powdered and transferred into polyethylene bags and treated with $10 \mathrm{kGy}$ of gamma rays, using Indian Gamma Cell ( Ge $4000 \mathrm{~A}){ }^{60} \mathrm{Co}$ source at a dose rate of $1.667 \mathrm{kGy} / \mathrm{h}$ at the National Centre for Radiation Research and Technology (NCRRT), Egypt.

Preparation of the aqueous extract of raw and gammairradiated frankincense oleogum resin (RFAE and GFAE)

A volume of $50 \mathrm{ml}$ of boiling-hot distilled water was poured on $625 \mathrm{mg}$ of the resin in a beaker. The mixture was allowed to stand for $30 \mathrm{~min}$ before it was filtered with a filter paper. An equivalent extract from $12.5 \mathrm{mg}$ dried plant material per $\mathrm{ml}$ aqueous infusion was obtained. The extract was always freshly prepared so as to prevent growth of fungi (Yassin et al., 2013).

Determination of total phenols and flavonoids of raw and gamma-irradiated frankincense oleogum resin (RFAE and GFAE)

Either raw or gamma-irradiated Boswellia oleogum resin water extract were analyzed for their total phenols using the Folin-Ciocalteau method according to Marinova et al. (2005), flavonoids by aluminium chloride colourimetric method according to Marinova et al. (2005).

\section{Animals}

The experiment was conducted on 28 male rats (170 to 200g body weight (B.WT)) purchased from the Egyptian Holding Company for Biological Products and Vaccines (Cairo, Egypt). Rats were acclimated to controlled laboratory conditions for two weeks. Rats were maintained on stock rodent diet and tap water that were allowed ad libitum. All animals procedures were carried out in accordance with the Ethics Committee of the National Research Centre conformed to the Guide for the Care and Use of Laboratory Animals, published by the US National Institutes of Health (NIH Publication No. 85 $-23,1996)$.

\section{Induction of MI by ISO}

The induction of MI was performed in the Infarcted group by subcutaneous injection of $100 \mathrm{mg} / \mathrm{kg}$ isoprenaline hydrochloride dissolved in $2 \mathrm{ml}$ saline once daily for two successive days (Zaafan et al., 2013). The false induction of $\mathrm{MI}$ in the control group was performed by subcutaneous administration of $2 \mathrm{ml}$ of saline on two consecutive days.

\section{Grouping of animals}

The animal were randomly divided into 4 groups, each consisted of 7 rats. (i) Control group, rats administrated with $2 \mathrm{ml}$ saline and served as control. (ii) ISO-treated group (Infarcted group), rats were subcutaneous injected with isoprenaline hydrochloride $(100 \mathrm{mg} / \mathrm{kg} \mathrm{B}$.Wt./day) dissolved in $2 \mathrm{ml}$ saline in the last 2 days of treatment (Zaafan et al., 2013). (iii) Group RFAE\&ISO, Rats orally given raw frankincense aqueous extract (RFAE) at a dose of $45 \mathrm{mg} / \mathrm{kg} / \mathrm{day}$ (Yassin et al., 2013) for 4 weeks and subcutaneous injected with ISO (100 mg/ kg B.Wt./day) in the last 2 days of treatment. (iv) Group GFAE\&ISO, rats orally given gamma-irradiate frankincense aqueous extract (GFAE) at a dose of $45 \mathrm{mg} / \mathrm{kg} / \mathrm{day}$ (Yassin et al., 2013) for 4 weeks and subcutaneous injected with ISO $(100 \mathrm{mg} / \mathrm{kg}$ B.Wt./day) in the last 2 days of treatment.

At the end of the experiment, animals from each group were sacrificed $24 \mathrm{~h}$ post the last dose of treatment. Blood samples were withdrawn by cardiac puncture after slight anathesation of rats using diethyl ether and allowed to coagulate and centrifuged to get serum for biochemical analysis.

\section{Biochemical analysis}

Serum levels of tumor necrotic factor-alpha (TNF- $\alpha$ ), interleukin-6 (IL-6), creatinine kinase-MB (CK-MB) and cardiac troponin I (cTnI) were performed by ELISA technique (BioSource International, Camarillo, CA, USA) according to the manufacturer's instructions. The levels of lactate dehydrogenase (LDH) and was determined by the method of King (1965), aspartate transaminase (AST) and alanine transaminase (ALT) were determined according to the Reitman and Frankel (1957). Total cholesterol (TC), triglycerides (TG) and high-density lipoproteincholesterol (HDL-C) were determined according to procedure described by Allain et al. (1974), Fossati and Prencipe (1982) and Demacker et al. (1980), respectively. 
Low-density lipoprotein-cholesterol (LDL-C), very low-density lipoprotein-cholesterol and risk ratio were evaluated according to Friedwald's formula (Friedwald et al., 1972) by the following equations: LDL-C $(\mathrm{mg} / \mathrm{dl})=$ TC-(TG/5+HDL-C), vLDL (mg/dl) = TG/5.

Heart tissues were dissected, thoroughly washed with ice-cold $0.9 \% \mathrm{NaCl}$, weighed, minced and homogenized (10\% w/v) using $66 \mathrm{mmol} / \mathrm{L}$ chilled phosphate buffer (pH 7.0). The tissue homogenates were centrifuged at $6000 \mathrm{rpm}$ for $15 \mathrm{~min}$ and the supernatants were used to estimate thiobarbituric acid reactive substances (TBARS) (Yoshioka et al., 1979), glutathione content (GSH) (Beutler et al., 1963), and for the assays of the activity of superoxide dismutase (SOD) (Minami and Yoshikawa, 1979) and catalase (CAT) (Johansson and Borg, 1988).

\section{Statistical analysis}

Results were presented as mean \pm SE $(n=7)$. Experimental data were analyzed using one way analysis of variance (ANOVA). Duncan's multiple range test was used to determine significant differences between means. The statistical analyses were performed using computer program Statistical Packages for Social Science (1998). Differences between means were considered significant at $\mathrm{P}<0.05$.

\section{RESULTS}

The analysis of raw Boswellia carteri oleo-gum resins water extract indicated that each $100 \mathrm{ml}$ of the tested Boswellia carteri gum resin water extract content total phenols was about $182 \pm 3.2 \mathrm{mg}$ GAE and $0.60 \pm 0.02 \mathrm{mg}$ catechin equivalent for flavonoids and these values were increased significantly under the effect of gamma-rays by percent change $4.9 \%$ and $6.6 \%$, respectively (Table I).

Table I.- Total phenolic and total flavonoids of raw and $\gamma$-irradiated Boswellia oleo-gum resin water extract.

\begin{tabular}{lccc}
\hline Parameters & \multicolumn{2}{c}{$\begin{array}{c}\text { Boswellia oleogum } \\
\text { resin water extract }\end{array}$} & \\
\cline { 2 - 3 } & Raw & Irradiated & \\
\hline Total phenolic content & $182.0 \pm$ & $191.0 \pm$ & $4.9 \%$ \\
(mg gallic acid equivalent/100ml & 3.2 & 3.5 & \\
tested water extract $\pm \mathrm{SD}$ ) & & & \\
Total flavonoids & $0.60 \pm$ & $0.64 \pm$ & $6.6 \%$ \\
(mg catechin equivalent $/ 100 \mathrm{ml}$ & 0.02 & 0.02 & \\
tested water extract $\pm \mathrm{SD}$ ) & & & \\
\hline
\end{tabular}

Values are means of three replicates $( \pm \mathrm{SD})$.

The obtained results revealed that subcutaneous injection with ISO induced remarkable increase in the inflammatory factors concentration (TNF- $\alpha$ and IL-6), significant increase in the level of cardiac marker enzymes (ALT, AST, LDH, CK-MB and cTnI) and significant increase in the level of TC, TG, LDL-C and vLDL-C compared to control and other groups. Pretreatment of infarcted group with either RFAE or GFAE induced significant reduction in the levels of ALT, AST, LDH, CKMB , cTnI, TNF- $\alpha$, IL-6, TC, TG, LDL-C and vLDL-C relative to non-treated ISO-group (Tables II, III, IV).

Table II.- Protective effect of raw and gamma-irradiate frankincense aqueous extract on the level of TNF- $\alpha$ and IL-6 in isoprenaline-induced myocardial infarction in rats.

\begin{tabular}{lcccc}
\hline Parameters & Control & ISO & ISO\&RFAE & ISO\&GFAE \\
\hline TNF- $\alpha$ & $674.32 \pm$ & $885.96 \pm$ & $702.58 \pm$ & $695.87 \pm$ \\
$(\mathrm{pg} / \mathrm{mL})$ & $42.55^{\mathrm{c}}$ & $53.65^{\mathrm{a}}$ & $47.37^{\mathrm{b}}$ & $48.11^{\mathrm{b}}$ \\
$\mathrm{IL}-6$ & $340.12 \pm$ & $482.28 \pm$ & $384.68 \pm$ & $375.92 \pm$ \\
$(\mathrm{pg} / \mathrm{mL})$ & $22.35^{\mathrm{c}}$ & $29.52^{\mathrm{a}}$ & $27.45^{\mathrm{b}}$ & $25.82^{\mathrm{b}}$ \\
\hline
\end{tabular}

Means in the same row with different superscripts are significantly different at $(\mathrm{P}<0.05)$, Values are expressed as mean \pm S.E. $(\mathrm{n}=7)$. ISO, Isoprenaline; RFAE, raw frankincense aqueous extract; GFAE, gammairradiate frankincense aqueous extract; $\mathrm{TNF}-\alpha$, tumor necrotic factoralpha; IL-6, interleukin-6

Table III.- Protective effect of raw and gammairradiate frankincense aqueous extract on the level of CK-MB, cTnI, LDH, ALT and AST in isoprenaline -induced myocardial infarction in rats.

\begin{tabular}{lcccc}
\hline Parameters & Control & ISO & $\begin{array}{c}\text { ISO \& } \\
\text { RFAE }\end{array}$ & $\begin{array}{c}\text { ISO \& } \\
\text { GFAE }\end{array}$ \\
\hline $\mathrm{CK}-\mathrm{MB}$ & $3.28 \pm$ & $7.65 \pm$ & $5.64 \pm$ & $5.57 \pm$ \\
$(\mathrm{ng} / \mathrm{mL})$ & $0.82^{\mathrm{c}}$ & $1.42^{\mathrm{a}}$ & $0.93^{\mathrm{b}}$ & $0.97^{\mathrm{b}}$ \\
$\mathrm{cTnI}$ & $26.45 \pm$ & $70.58 \pm$ & $38.88 \pm$ & $36.68 \pm$ \\
$(\mathrm{ng} / \mathrm{mL})$ & $1.50^{\mathrm{c}}$ & $3.76^{\mathrm{a}}$ & $2.75^{\mathrm{b}}$ & $2.54^{\mathrm{b}}$ \\
$\mathrm{LDH}$ & $711.42^{\mathrm{a}}$ & $1082.36 \pm$ & $876.19 \pm$ & $862.55 \pm$ \\
$(\mathrm{nmol} / \mathrm{ml})$ & $34.85^{\mathrm{c}}$ & $42.28^{\mathrm{a}}$ & $38.40^{\mathrm{b}}$ & $36.62^{\mathrm{b}}$ \\
$\mathrm{ALT}$ & $25.33 \pm$ & $46.77 \pm$ & $33.71 \pm$ & $32.53 \pm$ \\
$(\mathrm{U} / \mathrm{L})$ & $1.23^{\mathrm{c}}$ & $1.46^{\mathrm{a}}$ & $1.22^{\mathrm{b}}$ & $1.48^{\mathrm{b}}$ \\
$\mathrm{AST}$ & $34.66 \pm$ & $59.88 \pm$ & $41.45 \pm$ & $40.26 \pm$ \\
$(\mathrm{U} / \mathrm{L})$ & $1.82^{\mathrm{c}}$ & $2.47^{\mathrm{a}}$ & $1.58^{\mathrm{b}}$ & $1.73^{\mathrm{b}}$ \\
\hline
\end{tabular}

Means in the same row with different superscripts are sig nificantly different at $(\mathrm{P}<0.05)$, Values are expressed as mean \pm S.E. $(n=7)$. ALT, alanine transaminase; AST, aspartate transaminase; CK-MB, creatinine kinase-MB; cTnI, cardiac troponin I; LDH, lactate dehydrogenase. For other abbreviations, see Table II.

The results in Table $\mathrm{V}$ indicated that ISO injection to rats induced significant increase in the level of cardiac TBARS accompanied by reduction in the level of GSH and the activity of SOD and CAT compared to other groups. However, administration of rats with RFAE or GFAE before injection of ISO resulted in significant protection 
Table IV.- Protective effect of raw and gamma-irradiate frankincense aqueous extract on the level of lipid contents in isoprenaline-induced myocardial infarction in rats.

\begin{tabular}{lccccc}
\hline $\begin{array}{l}\text { Animal } \\
\text { groups }\end{array}$ & $\begin{array}{c}\text { TC } \\
(\mathbf{m g} / \mathbf{d l})\end{array}$ & $\begin{array}{c}\text { TG } \\
(\mathbf{m g} / \mathbf{d l})\end{array}$ & $\begin{array}{c}\text { HDL-C } \\
(\mathbf{m g} / \mathbf{d l})\end{array}$ & $\begin{array}{c}\text { LDL-C } \\
(\mathbf{m g} / \mathbf{d l})\end{array}$ & $\begin{array}{c}\text { vLDL-C } \\
(\mathbf{m g} / \mathbf{d l})\end{array}$ \\
\hline Control & $127.63 \pm 5.76^{\mathrm{c}}$ & $121.14 \pm 5.48^{\mathrm{c}}$ & $58.23 \pm 4.72^{\mathrm{a}}$ & $45.17 \pm 4.82^{\mathrm{c}}$ & $24.23 \pm 0.79^{\mathrm{c}}$ \\
ISO & $192.24 \pm 8.12^{\mathrm{c}}$ & $239.48 \pm 7.86^{\mathrm{a}}$ & $30.96 \pm 4.13^{\mathrm{c}}$ & $113.83 \pm 6.08^{\mathrm{a}}$ & $47.90 \pm 0.94^{\mathrm{a}}$ \\
ISO \& RFAE & $148.82 \pm 6.33^{\mathrm{b}}$ & $162.45 \pm 6.24^{\mathrm{b}}$ & $46.58 \pm 4.58^{\mathrm{b}}$ & $69.75 \pm 4.54^{\mathrm{b}}$ & $32.49 \pm 0.81^{\mathrm{b}}$ \\
ISO \& GFAE & $145.29 \pm 6.27^{\mathrm{b}}$ & $156.65 \pm 6.50^{\mathrm{b}}$ & $49.22 \pm 4.44^{\mathrm{b}}$ & $64.74 \pm 4.33^{\mathrm{b}}$ & $31.33 \pm 0.73^{\mathrm{b}}$ \\
\hline
\end{tabular}

Means in the same column with different superscripts are significantly different at $(\mathrm{P}<0.05)$, Values are expressed as mean \pm S.E. $(\mathrm{n}=7)$. TC, total cholesterol; TG, triglycerides; HDL-C, high-density lipoprotein-cholesterol; LDL-C, low-density lipoprotein-cholesterol; vLDL-C, very Low-density lipoprotein-cholesterol. For other abbreviations, see Table II.

Table V.- Protective effect of raw and gammairradiate frankincense aqueous extract on the cardiac antioxidant status in isoprenaline -induced myocardial infarction in rats.

\begin{tabular}{lcccc}
\hline Parameters & Control & ISO & $\begin{array}{c}\text { ISO \& } \\
\text { RFAE }\end{array}$ & $\begin{array}{c}\text { ISO \& } \\
\text { GFAE }\end{array}$ \\
\hline TBARS & $9.33 \pm$ & $17.23^{ \pm}$ & $12.83 \pm$ & $12.23 \pm$ \\
(n mol/g tissue) & $1.33^{\mathrm{c}}$ & $1.52^{\mathrm{a}}$ & $1.21^{\mathrm{b}}$ & $1.42^{\mathrm{b}}$ \\
GSH & $5.26 \pm$ & $2.29 \pm$ & $4.15 \pm$ & $4.28 \pm$ \\
(mg/g tissue) & $0.23^{\mathrm{a}}$ & $0.28^{\mathrm{c}}$ & $0.30^{\mathrm{b}}$ & $0.26^{\mathrm{b}}$ \\
SOD & $29.25 \pm$ & $18.17 \pm$ & $23.46 \pm$ & $24.23 \pm$ \\
(U/mg protein) & $1.37^{\mathrm{a}}$ & $1.27^{\mathrm{c}}$ & $1.48^{\mathrm{b}}$ & $1.50^{\mathrm{b}}$ \\
CAT & $39.60 \pm$ & $24.10 \pm$ & $30.18 \pm$ & $31.22 \pm$ \\
(U/g protein) & $1.23^{\mathrm{a}}$ & $1.15^{\mathrm{c}}$ & $1.28^{\mathrm{b}}$ & $1.22^{\mathrm{b}}$ \\
\hline
\end{tabular}

Means in the same row with different superscripts are significantly different at $(\mathrm{P}<0.05)$, Values are expressed as mean \pm S.E. $(\mathrm{n}=7)$ CAT, catalase; SOD, superoxide dismutase; GSH, glutathione content; TBARS, thiobarbituric acid reactive substances. For other abbreviations, see Table II.

against ISO-induced cardiac damage with significant elevation in the level of GSH and the activity of SOD and CAT and reduction in TBARS relative to infarcted group.

\section{DISCUSSION}

Myocardial infarction can be occurred due to interruption in the blood supply to any part of the heart which can lead to death of the cardiac tissue (myocardial necrosis) (Zaki et al., 2014). Also, excessive release of catecholamines is responsible for the development of various cardiac dysfunctions. Isoproterenol is used as a synthetic catecholamine to produce myocardial injury in animals that serves as an experimental model for the pharmacological evaluation of cardioprotective agents (Goyal et al., 2010). Frankincense (olibanum) is an aromatic resin obtained from trees of the genus Boswellia and has been used in traditional medicine in the treatment of rheumatoid arthritis and anti-inflammatory, antibacterial, antifungal and anticancer activities (Beheshti and Karimi, 2016).

The results of total phenolic and flavonoids of Boswellia carteri gum resin water extract indicated that using of gamma-radiation for both decontamination and sterilization of induced positive effect of frankincense chemical constituents and resulted in significant elevation of total phenolic and flavonoids content by percent change $4.9 \%$ and $6.6 \%$, respectively. These increases could be due to the ability of gamma-rays to induced decomposition of some large insoluble phenolic compounds into small soluble phenolic molecules (Hamza et al., 2012)

This study revealed that the subcutaneous administration of ISO to rats induces severe stress in the cardiac muscle leading to development of myocardial infarction. These results are evidenced by significant increase in the serum levels of heart marker enzymes (ALT, AST, LDH, CK-MB and cTnI) in infarcted group when compared to control and treated groups. It was observed that these cardio-specific marker enzymes are released from the heart into the blood during myocardial damage due to myofibril degeneration and myocyte necrosis (Senthil et al., 2007). Kurian et al. (2005) revealed that isoprenaline injection induced significant increase in the activities of cardiac markers (ALT, AST, LDH and CK) in ISO-treated rats and that might be due to enhanced susceptibility of myocardial cell membrane to the ISO mediated peroxidative damage, resulting in increased release of these diagnostic marker enzymes into the systemic circulation. Furthermore, ISO induced oxidative stress and excessive generation of ROS that directly injure the cell membrane result in leakage of cardiac enzymes in serum (Shi et al., 2013).

ISO administration to rats in this work is associated with inflammation and elevation of inflammatory cytokines (TNF- $\alpha$ and IL-6) in infarcted group when compared to 
control and treated groups. This result is in agree with Rajappa et al. (2009) reported that myocardial infarction is found to be associated with inflammation with elevation of pro-inflammatory cytokines (such as TNF- $\alpha$ and IL6). Gasparyan (2012) reported that inflammation has been recognized as a major driving force in the ischemic process, and increasing evidence has shown that enhanced levels of inflammatory markers are related to ischemia. Also, ROS produced by ISO stimulate signal transduction to elaborate inflammatory cytokines ( TNF- $\alpha$, interleukin (IL)-1 $\beta$, and -6) in the ischemic region and surrounding myocardium and these inflammatory cytokines, also, regulate cell survival and cell death in the chain reaction with ROS (Fantinelli et al., 2013).

The results of infarcted group indicate that ISO injection induced significant increase in the level of TC, TG, LDL-C and vLDL-C with significant decrease in the level of HDL-C relative to the other groups. These alterations in the lipid contents could be as a result of induction of lipid biosynthesis by cardiac cyclic adenosine monophosphate (Senthil et al., 2007). Also, ISO-induced disturbance in lipid metabolism can alter the cardiac function by changing the properties of cardiac cell membrane and these changes may contribute to the cell death (Priscilla and Prince, 2009). Furthermore, the effect of ISO could be occurred due to induction of free radicals accumulation, which may cause cellular cholesterol accumulation, by increasing cholesterol biosynthesis and its esterification, decreasing cholesterol ester hydrolysis, and reducing cholesterol efflux (Spiteller, 2005).

Regarding to the antioxidant status of infracted rats the results indicated that ISO induced significant increase in the level of TBARS with obvious reduction in GSH concentration and the activity of SOD and CAT of cardiac tissues comparing to control group. These results are in agreement with other observations that reported the involvement of oxidative stress and lipid peroxidation in ISO-induced cardiac hypertrophy and cardiotoxicity (Banerjee et al., 2003; Shikalgar and Naikwade, 2010). ISO induced occurrence of oxidative stress as a results of a serious imbalance between the generation of reactive oxygen species (ROS) and their clearance by the body's endogenous antioxidative defenses (Noreen et al., 2018). Moreover, the excessive reduction in the antioxidant status and increasing in lipid peroxidation following ISO administration indicate irresistibility of the free radicals, which cause oxidative damage to the myocardial cell (Goyal et al., 2015).

On the other wide, the results of this study indicated that administration of either RFAE or GFAE before induction of infarct-like lesion by ISO resulted in amelioration of cardiac injury. Specifically, there were significant reductions in the activity of cardiac marker enzymes (ALT, AST, LDH, CK-MB and cTnI) and remarkable down regulation of inflammatory cytokines (TNF- $\alpha$ and IL-6). Also, pretreatment with RFAE or GFAE induced an obvious increase in the level of HDL-C with reduction in the level of TC, TG, LDL-C and vLDL-C as well as an obvious induction in the cardiac total antioxidant capacity and reduction in the level of MDA relative to the non treated infracted groups. The antiinflammatory effect of either RFAE or GFAE against ISOinduced myocardial inflammation might be to the active compound of frankincense that exhibit anti-inflammatory property in human peripheral blood mononuclear cells and mouse macrophages through inhibition of TNF- $\alpha$, IL-1 $\beta$, NO and mitogen activated protein kinases (Ammon, 1996; Beheshti and Karimi, 2016). Boswellic acids are the main active components of the resin of Boswellia carteri and were shown to down regulate the pro-inflammatory cytokines including TNF- $\alpha$, IL- $1 \beta$, IL-2, IL- 6 and INF- $\gamma$ by interacting with the production of these cytokines (Ammon, 2010). Incensole acetate is another active component of frankincense was also shown to inhibit activation of nuclear factor-kappa B (NF-кB), a transcription factor which is crucial for inflammatory responses (Moussaieff et al., 2007). Also, this study indicated that treatment with RFAE or GFAE resulted in significant hypo-lipidemic effect relative to ISO-injected rats and these results were in agreement with those of Pandey et al. (2005). Al-Yasiry et al. (2016) suggested that the reducing effect of Boswellia serrata resin gum resins on lipid contents could be attributed to the possibility that Boswellia serrata supplementation restores $\beta$-cells function for insulin secretion, and that insulin helps to reduce serum lipid profiles.

Moreover, the group of rats treated with either RFAE or GFAE prior to subcutaneous injection with ISO exhibited higher level of cardiac GSH concentration and the activity of SOD and CAT and Lower level of cardiac TBARS than those of infarcted group. Thus, this study has shown that frankincense possesses powerful antioxidant activity. Sharma et al. (2011) indicated that the aqueous extract of $B$. serrata has persuasive anti-oxidant activity in removing free radicals in a concentration-dependent manner. Additionally, Afsar et al. (2012) performed that, the extract from B. serrata contains high amounts of total phenolics and total flavonoids and it exhibited high reducing power, antioxidant activity and anti-inflammatory activity. Also, the active ingredients of frankincense such as boswellic acid containing antioxidant properties and act as free radical scavengers, and sometimes as metal chelators, acting as the initiation step in the propagation of 
antioxidative process (Renata et al., 2012).

\section{CONCLUSION}

The results showed that gamma-irradiation resulted in significant increases in total phenolic content and total flavonoids which indicated that this method could be suggested as an efficient method for sterilization of Boswellia carterii oleogum resin. Additionally, based on the findings of this study, it can be argued that pretreatment with gamma-irradiate frankincense aqueous extract provide significant cardio protective, hypo-lipidemic, antiinflammatory and antioxidant effects against isoprenalineinduced infarct-like lesion in rats.

\section{Statement of conflict of interest}

The authors declare that there is no conflict of interests regarding the publication of this article.

\section{REFERENCES}

Afsar, Y., Mohan, R. and Saritha, K., 2012. In vitro antioxidant activity and anti-inflammatory activity of methanolic leaf extract of Boswellia serrata. Int. J. Life Sci. Biotechnol. Pharm. Res., 1: 2250-2256.

Al-Daraji, J., Ahmed, A.S. and Al-Yasery, A.R.M., 2013. Effect of supplementation of different levels frankincense to drinking water on certain hematological traits of broiler. J. biol. Chem. environ. Sci., 8: 589-601.

Allain, C.C., Poon, L.S., Chan, C.S., Richmond, W. and Fu, P.C., 1974. Enzymatic determination of total serum cholesterol. Clin. Chem., 20: 470.

Al-Yasiry, A.R.M. and Kiczorowska, B., 2016. Frankincense -therapeutic properties. Postepy. Hig. Med. Dosw. (Online), 70: 380-391.

Al-Yasiry, R.M.A., Jawad, S.A.H., Menati, K.J., Naji, S.A. and Lokman, I.H., 2016. Effects of Boswellia carterii and Boswellia serrata in drinking water on the growth performance, hematology traits and immune response of broiler chicken. Res. Rev. J. Fd. Dairy Technol., 4: 27-37. https://doi. org/10.5604/17322693.1200553

Ammon, H.P., 1996. Salai Guggal - Boswellia serrata: From a herbal medicine to a non-redox inhibitor of leukotriene biosynthesis. Eur. J. med. Res., 1: 369370.

Ammon, H.P., 2010. Modulation of the immune system by Boswellia serrata extracts and boswellic acids. Phytomedicine, 17: 862-867. https://doi. org/10.1016/j.phymed.2010.03.003

Badr, P., Daneshamouz, S., Mohammadi, A.A.,
Akbarizadeh, A.R. and Afsharypuor, S., 2016. The effect of 60Co-gamma radio-sterilization on Boswellia carterii essential oil composition. Res. J. Pharmacog., 3: 67-74.

Banerjee, S.K., Sood, S., Dinda, A.K., Das, T.K. and Maulik, S.K., 2003. Chronic oral administration of raw garlic protects against isoproterenol-induced myocardial necrosis in rat. Comp. Biochem. Physiol. Part C: Toxicol. Pharmacol., 136: 377386. https://doi.org/10.1016/j.cca.2003.10.011

Beheshti, S. and Karimi, B., 2016. Frankincense improves memory retrieval in rats treated with lipopolysaccharide. J. Herb. Med. Pharmacol., 5: 12-16.

Beutler, E., Duron, O. and Kelly, B.M., 1963. Improved method for the determination of blood glutathione. J. Lab. Clin. Med., 61: 882-888.

Demacker, P.N., Vos-Janssen, H.E., Hifmans, A.G.M., Van't Laar, A. and Jansen, A.P., 1980. Measurement of high-density lipoprotein cholesterol in serum: Comparison of six isolation methods combined with enzymatic cholesterol analysis. Clin. Chem., 26: 1780.

Fantinelli, J.C., González-Arbeláez, L.F., Pérez-Núñez, I.A. and Mosca, S.M., 2013. Protective effects of $\mathrm{N}$-(2-mercaptopropionyl)-glycine against ischemia-reperfusion injury in hypertrophied hearts. Exp. Mol. Pathol., 94: 277-284. https://doi. org/10.1016/j.yexmp.2012.07.004

Fossati, P. and Prencipe, L., 1982. Serum triglycerides determined calorimetrically with an enzyme that produce hydrogen peroxide. Clin. Chem., 28: 2077.

Friedwald, W.T., Levy, R.I. and Fredrickson, D., 1972. Estimation of concentration of low-density lipoprotein cholesterol in plasma without use of the preparative ultracentrifuge. Clin. Chem., 18: 499.

Gasparyan, A.Y., 2012. Cardiovascular risk and inflammation: Pathophysiological mechanisms, drug design, and targets. Curr. Pharmaceut. Design., 18: 1447-1449. https://doi. org/10.2174/138161212799504777

Goyal, S.N., Sharma, C., Mahajan, U.B., Patil, C.R., Agrawal, Y.O., Kumari, S., Arya, D.S. and Ojha, S., 2015. Protective effects of cardamom in isoproterenol-induced Myocardial infarction in rats. Int. J. mol. Sci., 16: 27457-27469. https://doi. org/10.3390/ijms161126040

Goyal, S.N., Arora, S., Sharma, A.K., Joshi, S., Ray, R., Bhatia, J., Kumari, S. and Arya, D.S., 2010. Preventive effect of crocin of Crocus sativus on hemodynamic, biochemical, histopathological and ultrastuctural alterations in isoproterenol-induced 
cardiotoxicity in rats. Phytomedicine, 17: 227-232. https://doi.org/10.1016/j.phymed.2009.08.009

Hamza, R.G., Afifi, S., Abdel-Ghaffar, A.R.B. and Borai, I.H., 2012. Effect of gamma-irradiation or/ and extrusion on the nutritional value of soy flour. Biochem. Analyt. Biochem., 1: 118. https://doi. org/10.4172/2161-1009.1000118

Johansson, L.H. and Borg, L.A.H., 1988. A spectrophotometric method for determination of catalase activity in small tissue samples. Analyt. Biochem., 74: 331. https://doi.org/10.1016/00032697(88)90554-4

Kannan, M.M. and Quine, S.D., 2013. Ellagic acid inhibits cardiac arrhythmias, hypertrophy and hyperlipidaemia during myocardial infarction in rats. Metabolism, 62: 52-61. https://doi. org/10.1016/j.metabol.2012.06.003

King, J. (ed.), 1965. The dehydrogenases or oxidoreductases-lactate dehydrogenase. In: Practical clinical enzymology. Van Nostrand Company Ltd., London, pp. 83-93.

Kurian, G.A., Philp, S. and Varghese, T., 2005. Effect of aqueous extract of Desmodium gangeticum DC root in the severity of myocardial infarction. J. Ethanopharmcol., 97: 4557-4561. https://doi. org/10.1016/j.jep.2004.11.028

Marinova, D., Ribarova, F. and Atanassova, M., 2005. Total phenolics and total flavonoids in Bulgarian fruits and vegetables. J. Univ. Chem. Technol. Metallur., 40: 255-260.

Minami, M. and Yoshikawa, H., 1979. A simplified assay method of superoxide dismutase activity for clinical use. Clin. Chim. Acta, 92: 337-342. https:// doi.org/10.1016/0009-8981(79)90211-0

Moussaieff, A., Shohami, E., Kashman, Y., Fride, E., Schmitz, M.L., Renner, F., Fiebich, B.L., Munoz, E., Ben-Neriah, Y. and Mechoulam, R., 2007. Incensole acetate, a novel antiinflammatory compound isolated from Boswellia resin, inhibits nuclear factor-kappa B activation. Mol. Pharmacol., 72: 1657-1664. https://doi. org/10.1124/mol.107.038810

Noreen, A., Bukhari, D.A. and Rehman, A. 2018. Reactive oxygen species: Synthesis and their relationship with cancer-a review. Pakistan J. Zool., 50:1951-1963, 2018. http://dx.doi.org/10.17582/ journal.pjz/2018.50.5.1951.1963

Pandey, S., Singh, B.K. and Tripathi, Y.B., 2005. Extract of gum resins of Boswellia serrata L. inhibits lipopolysaccharide induced nitric oxide production in rat macrophages along with hypolipidernic property. Indian J. exp. Biol., 43: 509-516.
Priscilla, D.H. and Prince, P.S., 2009. Cardioprotective effect of gallic acid on cardiac troponin-T, cardiac marker enzymes, lipid peroxidation products and antioxidants in experimentally induced myocardial infarction in Wistar rats. Chem. Biol. Interact., 179: 118-124. https://doi.org/10.1016/j.cbi.2008.12.012

Rajappa, M, Sen, S.K. and Sharma, A., 2009) Role of pro-/anti-inflammatory cytokines and their correlation with established risk factors in South Indians with coronary artery disease. Angiology, 60: 419. https://doi.org/10.1177/0003319708321101

Reitman, S. and Frankel, S., 1957. A calorimetric method for the determination of serum glutamic oxalacetic and glutamic pyruvic transaminases. Am. J. clin. Pathol., 28: 56. https://doi.org/10.1093/ ajcp/28.1.56

Renata, M., Maria, I., Juliana, T., Henrique, S. and Norma, P., 2012. Effect of Boswellia serrata on antioxidant status in an experimental model of colitis rats induced by acetic acid. Digest. Dis. Sci., 57: 2038. https://doi.org/10.1007/s10620-0122134-3

Senthil, S., Sridevi, M. and Pugalendi, K.V., 2007. Protective effect of Ursolic acid against myocardial ischemia induced by isoproterenol in rats. Toxicol. Mech. Methods, 17: 57-65. https://doi. org/10.1080/15376510600822649

Sharma, A., Upadhyay, J., Jain, A., Kharya, M.D., Namdeo, A. and Mahadik, K.R., 2011. Antioxidant activity of aqueous extract of Boswellia serrata. $J$. Chem. Biol. Physic. Sci., 1: 60-71.

Shi, M., He, W., Liu, Y., Li, X., Yang, S. and Xu, Q., 2013). Protective effect of total phenylethanoid glycosides from Monochasma savatieri. Phytomedicine, 20: 1251-1255. https://doi. org/10.1016/j.phymed.2013.06.014

Shikalgar, T.S. and Naikwade, N.S., 2010. Verapamil ameliorates cardio protective potential of vitamin $\mathrm{E}$ in myocardial oxidative damage induced by isoproterenol: A biochemical study. J. Pharma. Sci. Technol., 2: 298-302.

Spiteller, G., 2005. The relation of lipid peroxidation processes with atherogenesis: A new theory on atherogenesis. Mol. Nutr. Mol. Res., 49: 999-1013. https://doi.org/10.1002/mnfr.200500055

SPSS, 1998. Statistical package for social science. Computer software, Ver. 10. SPSS Company, London, UK.

Upaganlawar, A., Gandhi, H. and Balaraman, R., 2010. Effect of vitamin $\mathrm{E}$ alone and in combination with lycopene on biochemical and histopathological alterations in isoproterenol induced myocardial 
infarction in rats. J. Pharmacol. Pharmacother., 1: 24-31. https://doi.org/10.4103/0976-500X.64532

Yassin, N., El-Shenawy, S., Mahdy, K.A., Gouda, N., Marrie, A., Farrag, A. and Ibrahim, B.M.M., 2013. Effect of Boswellia serrata on Alzheimer's disease induced in rats. J. Arab Soc. Med. Res., 8: 1-11.

Yoshioka, T., Kawada, K., Shimada, T. and Mori, M., 1979. Lipid peroxidation in maternal and cord blood and protective mechanism against activated-oxygen toxicity in the blood. Am. J. Obstet. Gynecol., 135: 372-376. https://doi.org/10.1016/00029378(79)90708-7
Zaafan, M.A., Zaki, H.F., El-Brairy, A.I. and Kenawy, S.A., 2013. Protective effects of atorvastatin and quercetin on isoprenaline-induced myocardial infarction in rats. Bull. Facul. Pharm. Cairo Univ., 51: 35-41. https://doi.org/10.1016/j. bfopcu.2013.03.001

Zaki, A.A., Hashish, N.E., Amer, M.A. and Lahloub, M.F., 2014. Cardioprotective and antioxidant effects of oleogum resin "Olibanum" from Boswellia carteri Birdw. (Bursearceae). Chinese J. Nat. Med., 12: 345-350. https://doi.org/10.1016/ S1875-5364(14)60042-X 